\title{
Influence of melatonin on glutathione system in rats skeletal muscle under alloxan induced diabetes
}

\author{
O.Yu. Kushnir, I.M. Yaremii, V.I. Shvets, N.V. Shvets \\ Higher education institution in Ukraine «Bukovinian State Medical University», Chernivtsi; \\ e-mail:kushnir@bsmu.edu.ua
}

\begin{abstract}
The aim was to determine the influence of melatonin on basal levels of glucose $(B G)$, the levels of protein carbonyl content, $\mathrm{Hb} \mathrm{A}_{1 \mathrm{c}}$ and thiobarbituric acid reactive compounds (TBCRC), reduced glutathione (GSH), activities of glutathione reductase [EC 1.6.4.2] (GR), glutathione peroxidase [EC 1.11.1.9] (GPX), glucose6-phosphate dehydrogenase [EC 1.1.1.49] (G-6-PhD) in the muscles of alloxan diabetic rats (DMIT). $B G$ levels in blood of rats with DMIT increased on 139\%, while in group of alloxan diabetic rats with impaired glucose tolerance (IGT) - were not differ from control. HbA $A_{1 c}$ levels in the blood of animals with $D M 1 T$ and IGT exceeded control by $219 \%$ and $123 \%$, the level of protein carbonyl groups - by $76 \%$ and $36 \%$, the level of TBCRC-by $58 \%$ and $36 \%$ respectively. Activities of GR, GPx, G-6-PhD and the level of GSH were decreased on $25 \%, 18 \%, 50 \%$ and $42 \%$ in rats with DMIT while in rats with IGT these indexes (besides GSH) were increased on 37\%, 22\%, 35\% respectively than control. Melatonin lowered the BG level on $56 \%$ in DMIT rats in comparison to initial levels. It normalized activities of GR, GPx, G-6-PhD and lipid peroxidation, and protein carbonylation as well as hemoglobin glycosylation, so these indexes did not differ from control. Thus, melatonin has strong potential to regulate glucose homeostasis through enhanced glucose consumption, decreased oxidative stress by activation of the glutathione protection system. Key words: melatonin; alloxan diabetes; glutathione system; skeletal muscle; rats.
\end{abstract}

\section{INTRODUCTION}

Diabetes mellitus can damage eyes, kidneys, nerves and heart. Microvascular and macrovascular disorders are the leading causes of morbidity and mortality in diabetic patients [1]. Hyperglycemia can increase the indicators of lipid peroxidation and oxidative stress in which free radicals fulfill the main role in the pathogenesis of these complications.

Alloxan diabetes was reported to induce oxidative stress and generates reactive oxygen species (ROS) [2]. In the presence of intracellular thiols, especially glutathione, alloxan generates ROS in a cyclic redox reaction with its reduction product, dialuric acid. Autoxidation of dialuric acid generates superoxide radicals, hydrogen peroxide and, in a final iron-catalysed reaction step, hydroxyl radicals. These hydroxyl radicals are ultimately responsible for the death of the beta cells, which have a particularly low antioxidative defence capacity, and the ensuing state of insulin-dependent 'alloxan diabetes'.

Type 1 diabetes mellitus (DM1T) is characterized by autoimmunity against pancreatic $\beta$ cells, resulting in their destruction and the patients' subsequent dependency on lifelong insulin replacement. DM1T patients have many complications, including cardiovascular, renal, and retinal disorders. Among them, skeletal muscle is a major target tissue of diabetic damage. Skeletal muscle is one of the largest organs in the human body and is, quantitatively, the most important tissue involved in maintaining glucose homeostasis under insulinstimulated conditions. Type 1 diabetic subjects without insulin treatment display a dramatic loss of muscle, which leads to a higher blood glucose concentration, resulting in a vicious cycle [3].

Melatonin (N-acetyl-5-methoxytryptamine) is the major product of the pineal gland, which functions as a regulator of sleep, circadian 
rhythm, and immune function. Melatonin and its metabolites have potent antioxidant/antiinflammatory properties, and they have proven to be highly effective in a variety of disorders linked to inflammation and oxidative stress [4,5]. Melatonin not only neutralizes reactive oxygen species (ROS), but also acts through the stimulation of several antioxidative enzymatic systems and stabilizing cell membranes [6].

The influence of melatonin on glutathione system in muscles of alloxan-induced diabetic rats is poorly understood. The present study evaluated whether melatonin administration would have protective effect against muscle alloxan-induced changes in glutathione turnover.

The aim was to determine the influence of melatonin on basal levels of glucose (BG), the levels of protein carbonyl content, $\mathrm{HbA}_{1 \mathrm{c}}$ and thiobarbituric acid reactive compounds (TB$\mathrm{CRC})$, reduced glutathione (GSH), activities of glutathione reductase [EC 1.6.4.2] (GR), glutathione peroxidase [EC 1.11.1.9] (GPx), glucose6-phosphate dehydrogenase [EC 1.1.1.49] (G$6-\mathrm{PhD})$ in the muscles of alloxan diabetic rats.

\section{METHODS}

Research performed in compliance with the Rules of the work using experimental animals (1977) and the Council of Europe Convention on the Protection of Vertebrate Animals used in experiments and other scientific purposes (Strasbourg, 1986), according to directions of International Committee of Medical Journals Editors (ICMJE), as well as "Bioethical expertise of preclinical and other scientific research conducted on animals" (Kyiv, 2006). Diabetes was induced in male Wistar rats by single i.p. injection of alloxan $(170 \mathrm{mg} / \mathrm{kg})$ [7]. Four days after diabetes induction, rats were divided into diabetic (untreated) and melatonin-diabetic group $(10 \mathrm{mg} / \mathrm{kg}$ «Sigma» USA, daily and orally for 42 days starting from $5^{\text {th }}$ day) [8]. Among diabetic rats were rats with preserved normoglycemia (impaired glucose tolerance - IGT) and rats with diabetes mellitus (DM1T) $\mathrm{BG} \geq$
$8.0 \mathrm{mmol} / 1$. Animals belonged to the group with IGT when they detected a statistically significant increase in the level of postprandial glycemia $>$ $9.0 \mathrm{mmol} / 1$ ( 2 hours after food intake) as compared to the control rats, in which this score was within (7.6-9.0) mmol/1. Blood was taken from the tail vein on $4^{\text {th }}$ and $47^{\text {th }}$ day evaluate the BG level with the use of OneTouchUltra (LifeScan, USA). Animals were sacrificed at the 47-th day from the beginning of the experiment accordance with the ethical treatment of animals. The rectus femoris muscle tissue was quickly removed, rinsed in saline, blotted, weighed and homogenized. The homogenate, $5 \%$ in ice-cold $0,25 \mathrm{mM}$ tris-HCl-buffer ( $\mathrm{pH} 7.4$ ), was made using a homogenizer. The supernatant of the homogenate, prepared by ultracentrifugation for $10 \mathrm{~min}$ at $3000 \mathrm{~g}$ was used for measurement of enzyme activities. Oxidant status was assessed by measuring of protein carbonyl contents, TBCRC, GSH levels, GR, GPx, G-6-PhD activities and in addition the level of $\mathrm{HbA}_{1 \mathrm{C}}$ in the blood was determined. Determinations of the enzymes activities were by standard methods, concentration was measurement by spectrophotometer SP-46 / photocolorimeter KFK3 [9].

In the process of oxidative modification of proteins in the radicals of the aliphatic amino acid residues, aldehyde and ketone groups are formed. They interact with 2,4-dinitrophenylhydrazine (2,4-DNPH) to form 2,4-dinitrophenylhydrazones with a specific absorption spectrum. Aldehyde- and keto-derivatives which are neutral in nature are determined at a wavelength of $370 \mathrm{~nm}$, alkali - at $430 \mathrm{~nm}$ [10].

The composition of the incubation medium consisted of $0.8 \mathrm{ml}$ of $0.9 \% \mathrm{NaCl}, 0.2 \mathrm{ml}$ of $5 \%$ supernatant of muscle homogenate, $1 \mathrm{ml}$ of $1 \mathrm{M}$ 2.4-DNPH, $1 \mathrm{ml}$ of $10 \%$ trichloroacetic acid (TCA) solution. After incubation (1 hour at $37^{\circ} \mathrm{C}$ ) samples were centrifugated at $1800 \mathrm{~g}$ for 10 minutes. Formed sediment was washed three times by 5\% TCA solution. To the resulting precipitate was added $5 \mathrm{ml}$ of $8 \mathrm{M}$ urea solution, samples were kept in a boiling water bath until the precipitate dissolved. The level of protein 
carbonyl contents was calculated by using an absorption coefficient of $2.1 \times 10^{4} \cdot \mathrm{M}^{-1} \mathrm{~cm}^{-1}$. The results were expressed in terms of optical density per gram of tissue (OD / g tissue).

The method of TBCRC determination [11] is based on a spectrophotometric determination of the trimetinic colored complex formed from the TBCRC interaction with thiobarbituric acid. The composition of the reaction medium was: $1 \mathrm{ml}$ of $10 \%$ post-native supernatant of muscle homogenate; $1.5 \mathrm{ml}$ distilled $\mathrm{H}_{2} \mathrm{O} ; 0.2 \mathrm{ml}$ of 20 $\mu \mathrm{M} \mathrm{FeSO}_{4} ; 1 \mathrm{ml}$ of $0.8 \%$ TBC solution and 0.3 $\mathrm{ml}$ of $60 \%$ TCA solution. The optical density of the colored solution was measured on a photoelectrocolorimeter at a wavelength of $532 \mathrm{~nm}$. TBCRC content $(\mu \mathrm{mol} / \mathrm{g})$ is calculated based on the molar absorption coefficient $=1.56 \mathrm{x}$ $10^{5} \mathrm{M}^{-1} \cdot \mathrm{cm}^{-1}$.

The spectrophotometric/microplate reader assay method for GSH involves oxidation of GSH by the sulfhydryl reagent 5.5'-dithio-bis(2nitrobenzoic acid) (DTNB) to form the yellow derivative 5'-thio-2-nitrobenzoic acid (TNB), measurable at $412 \mathrm{~nm}$ [12].

The composition of the incubation medium of the experimental test consisted of: $0.1 \mathrm{ml}$ of $0.001 \mathrm{M}$ solution of the Elman reagent (4 mg DTNB in $10 \mathrm{ml}$ of $0.2 \mathrm{M}$ potassium sodium phosphate buffer, $\mathrm{pH} 8.0$ ), $3 \mathrm{ml}$ of $0.2 \mathrm{M}$ potassium sodium phosphate buffer $(\mathrm{pH} 8.0)$, $0.1 \mathrm{mM}$ GSH solution, $0.3 \mathrm{ml}$ of supernatant. The reaction was stopped by the addition of $10 \%$ TCA solution in 10 minutes. Measurements were made against a control sample (without a supernatant) at a wavelength of $412 \mathrm{~nm}$. Values were expressed in micromol per $1 \mathrm{~g}$ of tissue.

The activity of GR was determined [12] by the rate of glutathione recovery in the presence of NADPH. The GR activity was determined in a supernatant (1500 g, $10 \mathrm{~min}$ ) by decreasing the amount of NADPH in an incubation medium (3 $\mathrm{ml}$ ) of the following composition: $50 \mathrm{mM}$ Tris- $\mathrm{HCl}$ buffer (pH 7.5), 1 mM EDTA, 0.16 mM NADPH, $1 \mathrm{mM} \mathrm{GSSG}$ and $0.1 \mathrm{ml}$ of $5 \%$ supernatant. The activity of GR was expressed in micromol NADPH used in response to $1 \mathrm{mg}$ protein in $1 \mathrm{~min}$.
The activity of GPx was determined [12] by the amount of oxidized glutathione formed from reduced glutathione in the detoxification of hydrogen peroxide in the glutathione peroxidase reaction.

The composition of the incubation medium cosisted of $2.7 \mathrm{ml}$ tris- $\mathrm{HCl}$ buffer $(50 \mathrm{mM} \mathrm{pH}$ 7.4, sodium azide $12 \mathrm{mM}$, EDTA $6 \mathrm{mM}$ ), 0.1 $\mathrm{ml}$ of $2.5 \mathrm{mM}$ reduced glutathione, $0.1 \mathrm{ml}$ of $5 \%$ post-native supernatant of the muscles. The reaction was started by adding of 0.1 $\mathrm{ml} 0.5 \mathrm{mM}$ hydrogen peroxide to the sample and stopping after 5 minutes by adding $1 \mathrm{ml}$ of $10 \%$ TCA solution. Control sample was stopeded before the reaction has begun. After centrifugation at $1800 \mathrm{~g}$ for 15 minutes in a supernatant of muscle homogenate, the optical density of oxidized glutathione at $262 \mathrm{~nm}$ was measured on a spectrophotometer. The activity of the enzyme was expressed in nanomol of the formed oxidized glutathione for 1 minute per 1 mg of protein.

The investigation of $\mathrm{G}-6-\mathrm{PhD}$ activity was made [13] spectrophotometrically according to increase of the optical density at $340 \mathrm{~nm}$, which is due to the rise in the number of NADPH in the process of enzymatic reaction.

Final concentrations of the components of the reaction mixture: $6.22 \mathrm{mM}$ NADP, $10 \mathrm{mM}$ G-6-Ph. To the centrifuge tube: $2.6 \mathrm{ml}$ of 50 $\mathrm{mM}$ Tris-HCl buffer $(\mathrm{pH}=7.4)$ containing 0.1 $\mathrm{ml}$ of magnesium sulfate ( $3 \mathrm{~g}$ of magnesium sulfate diluted in $25 \mathrm{ml}$ of distilled water); $0.1 \mathrm{ml}$ NADP; $0.1 \mathrm{ml}$ of G-6-Ph; $0.1 \mathrm{ml}$ of $5 \%$ muscle homogenate prepared on $50 \mathrm{mM}$ Tris- $\mathrm{HCl}$ buffer $(\mathrm{pH}=7.4)$. Samples incubated for 15 minutes in a thermostat at $37^{\circ} \mathrm{C}$. The reaction stopped by the addition of $1 \mathrm{ml}$ of $10 \%$ TCA solution. Samples are centrifuged for 10 minutes $(3000 \mathrm{~g})$. The activity of G-6-PhD in the muscles of rats was expressed in nanomol in $1 \mathrm{~min}$ per $1 \mathrm{mg}$ of protein.

The blood samples were collected in EDTA anticoagulation bottles and sent cooled at $4{ }^{\circ} \mathrm{C}$. Determinations of $\mathrm{HbA}_{1 \mathrm{c}}$ were performed within three days using a kit Bio-Rad Laboratoria Inc., France. 
Total protein determination (according to Lowry). It is performed according to the process described by V. Gudumac and coauthors [11].

Statistical analysis was performed using Statistica 10 StatSoft Inc. To determine an adequate method of statistical estimation of the average difference between the study groups held preliminary check distribution quantities in samples. According to the criteria ShapiroWilk, which is used to assess the normality of distribution in the sample volume $n \leq 50$, all samples not received data on deviation of the distribution of samples from normal $(\mathrm{P}>0.05)$. Given these data, the use of Mann-Whitney test was considered sufficient for valid conclusions. Differences were considered to be statistically significant at $\mathrm{P} \leq 0.05[14,15]$.

\section{RESULTS AND DISCUSSION}

The blood glucose level (fig.1) of diabetic rats increased significantly by

$139 \%(\mathrm{P}=0.000079)$ compared with control value throughout the experimental period (42 days). Melatonin injections caused a sharp decrease by $56 \%(\mathrm{P}=0.00009)$ in the elevated serum glucose level in DM1T group of rats compared with BG level before treatment.

ROS reacts with some amino acid, producing anything from modified, denatured and non-functioning proteins that in further may be responsible for oxidative stress. Diabetic hyperglycemia, by the process of free radical production, causes protein glycation and oxidative degeneration. The degree of such protein glycation is estimated by using some biomarkers such as glycated hemoglobin. Alteration in function and structure of antioxidant protein enzymes may also be due to nonenzymatic glycation [16].

According to our own investigations (fig.2), $\mathrm{HbA}_{1 \mathrm{c}}$ levels in the blood of animals with DM1T and IGT exceeded control by $219 \%(\mathrm{P}=0.00003)$ and $123 \%(\mathrm{P}=0.00026)$ respectively. In rats with alloxan diabetes, the administration of melatonin during 42 days resulted in a decrease of $\mathrm{HbA}_{1 \mathrm{c}}$ level: in animals with DM1T by $45 \%$ $(\mathrm{P}=0.00011)$ compared to group of animals that did not receive correction; in rats with IGT, the normalization of this indicator was observed.

Possible link between melatonin and insulin interaction may be in its protective effect against free radical attack of $\beta$-cells Langergans islets in pancreas. In witness of such think we did the investigations of Langergans islets in our previous studies [14]. Histomorphological alterations in Langergans islets of pancreas in diabetic rats were recorded: their share reliable decreased by $55 \%$, numbers of beta-cells decreased by $90 \%$, percentage of beta-cells with necrosis was $97 \%$ respectively compared with the indices of control animals. Melatonin treatment caused a sharp decrease in the elevated serum glucose and partial regeneration/proliferation of $\beta$-cells of islets. It is concluded that the hypoglycemic

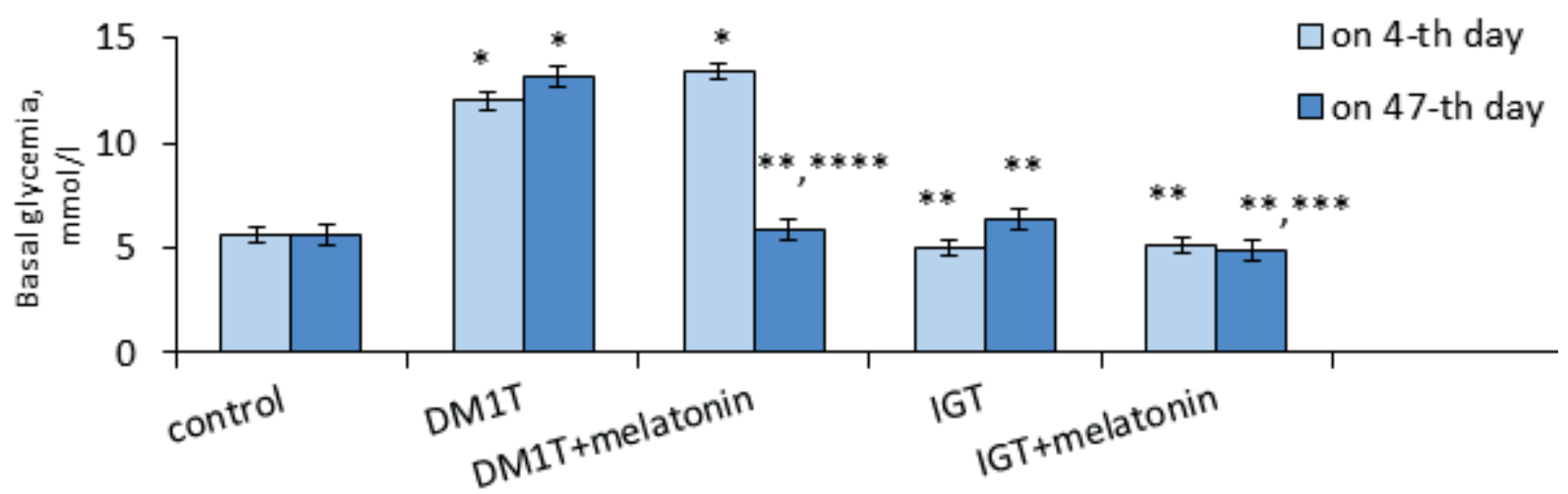

Fig. 1. The level of basal glycemia $(\mathrm{mmol} / \mathrm{l})$ in blood of rats, $(\mathrm{n}=6, \mathrm{x} \pm \mathrm{Sx}): 1 . *, * *, * * *, * * * *$ changes are reliable $(\mathrm{P} \leq 0.05) .2$. * - concerning control; ${ }^{*}$ - concerning rats with DM1T; *** - concerning rats with IGT; **** - concerning indices on 4-th day 


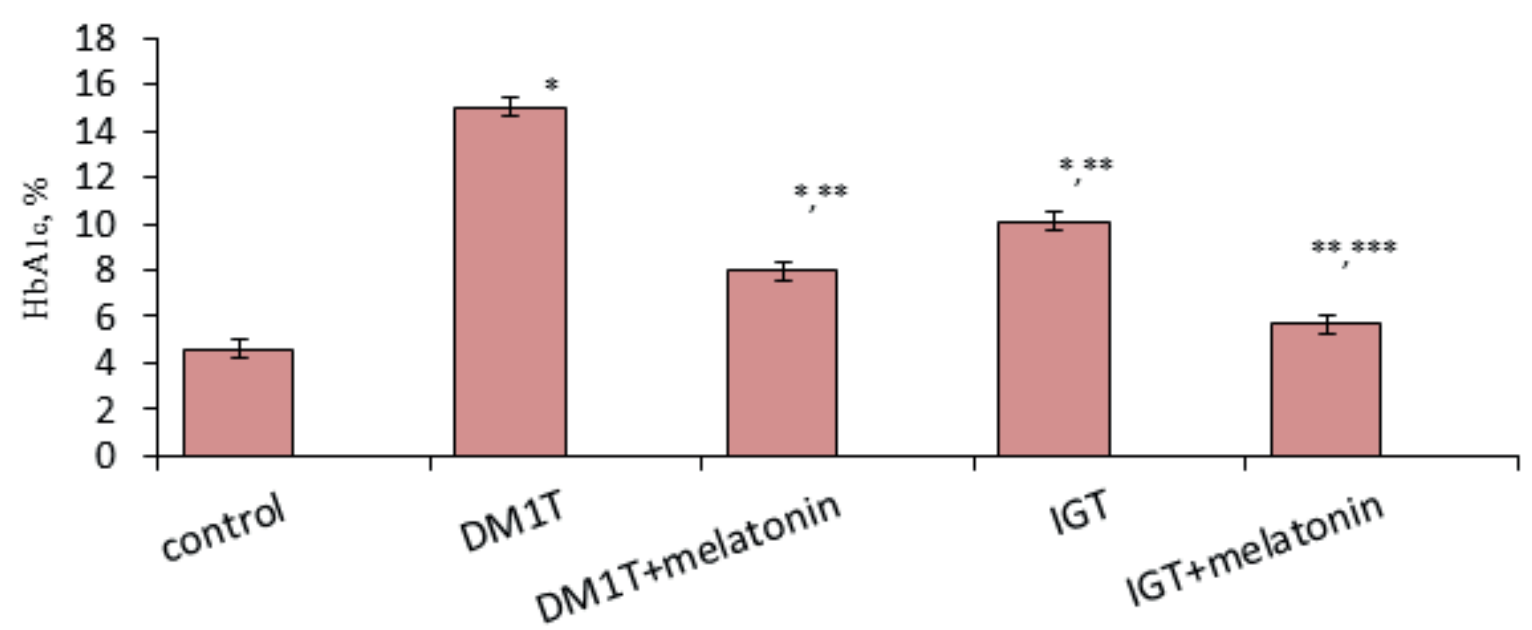

Fig. 2. The level of $\mathrm{HbA}_{1 \mathrm{c}}(\%)$ in blood of rats, $(\mathrm{n}=6, \mathrm{x} \pm \mathrm{Sx}): 1 . * * * * * *, * * * *-$ changes are reliable $(\mathrm{P} \leq 0.05) .2 . *-\mathrm{concerning}$ control; ** - concerning rats with DM1T; *** - concerning rats with IGT

action of melatonin could be partly due to amelioration in the beta-cells of pancreatic islets.

Results [17] indicate that melatonin treatment suppresses autoimmune recurrence by inhibiting the proliferation of Th1 cells in non obese diabetic mice and thus prolongs the survival of syngeneic islet grafts.

To access the protein oxidation mediated by glycation process, the levels of protein carbonyl content (fig. 3) were measured for the duration of 42 days.

The level of protein carbonyl groups was significantly increased in DM1T by $76 \%$ and in IGT by $36 \%$ compared with control, whereas melatonin treatment significantly suppressed an increase in protein carbonyl content. When comparing with index of diabetic rats, the percentage reduction of carbonyl content by melatonin was found to be $42 \%(\mathrm{P}=0.00044)$ and was not differ from control.

According to the results obtained, it may be postulated that melatonin inhibits glycation by reducing the generation of reactive carbonyl or dicarbonyl groups either from fructosamine or glucose, probably due to stimulation of glucose transport to skeletal muscle cells [18]

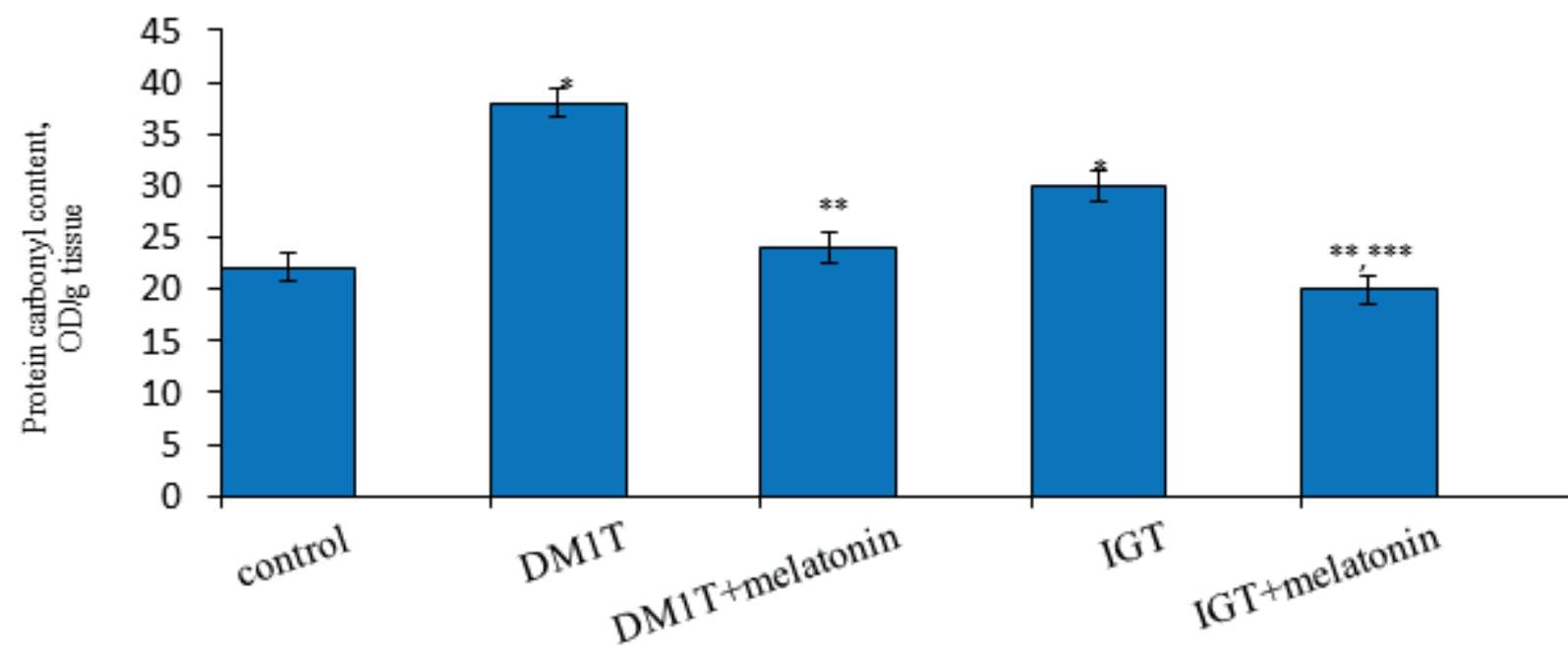

Fig. 3. The levels of protein carbonyl content in muscles of rats (OD / g tissue), $(\mathrm{n}=6, \mathrm{x} \pm \mathrm{Sx}): 1$. *, **, ***, **** - changes are reliable $(\mathrm{P} \leq 0.05) .2{ }^{*}$ - concerning control; $* *$ - concerning rats with DM1T; ***- concerning rats with IGT 
and preventing of ROS formation in conditions of hyperglycemia [16]. Diabetes mellitus produces disturbances in the lipid profile of body making the cells more susceptible to lipid peroxidation. Experimental studies [16] show that polyunsaturated fatty acids in cell membrane are extremely prone to attack by free radicals due to the presence of double bonds. Lipid peroxides through intermediate radical reactions produce such fatty acids that generate highly reactive and toxic lipid radicals that form new LHP. A critical biomarker of oxidative stress is Lipid peroxidation which is the most explored area of research when it comes to ROS. TBCRC are formed as a result of lipid peroxidation that can be used to measure lipid peroxides after reacting it with thiobarbituric acid. The level (fig.4) of TBCRC was found to be higher on $58 \%(\mathrm{P}=0.00089)$ in DM1T group and on $36 \%$ $(\mathrm{P}=0.0053)$ in IGT group respectively than in control on $47^{\text {th }}$ day of experiment.

So, the lipid peroxidation was increased in diabetic muscles. Melatonin partly prevented diabetes-induced increase in TBCRC in muscles.

Correspondingly, changes in the normal fiber type distribution are accompanied by changes in fuel oxidation and metabolic capacity of the muscle. Due to the reduced ability of skeletal muscle to access carbohydrates in times of inadequate/low insulin, diabetic skeletal muscle must promote the use of other fuel sources. Skeletal muscle of individuals with DM1T is associated with the excessive deposition of intramyocellular lipids (IMCL). This high level of IMCLs is noted in the muscle following food consumption, and very low levels in the fasted state, as this fuel source is heavily relied upon. Muscle from the streptozotocin DM1T mouse model also demonstrates increased acetyl CoA/ CoA ratio, hypothesized to be due to increased fatty acid oxidation, as well as increased fat utilization and mobilization, as the muscle tries to deal with the increased fat content. The alloxan-induced DM1T model similarly demonstrates an increase in free fatty acid levels in cardiac and skeletal muscle tissues. It is believed that as the levels of IMCL deposition increase, lipotoxicity ensues, enhancing stress to the tissue [19].

Diabetes induces alterations in activity of enzymes glutathione peroxidase and glutathione reductase (table). These enzymes are found in cell that metabolizes peroxide to water and converting glutathione disulfide back into glutathione. Any alteration in their levels will make the cells prone to oxidative stress and hence cell injury. So, the biochemical function of glutathione peroxidase is to reduce lipid hydroperoxides to their corresponding alcohols and to reduce free hydrogen peroxide to water.

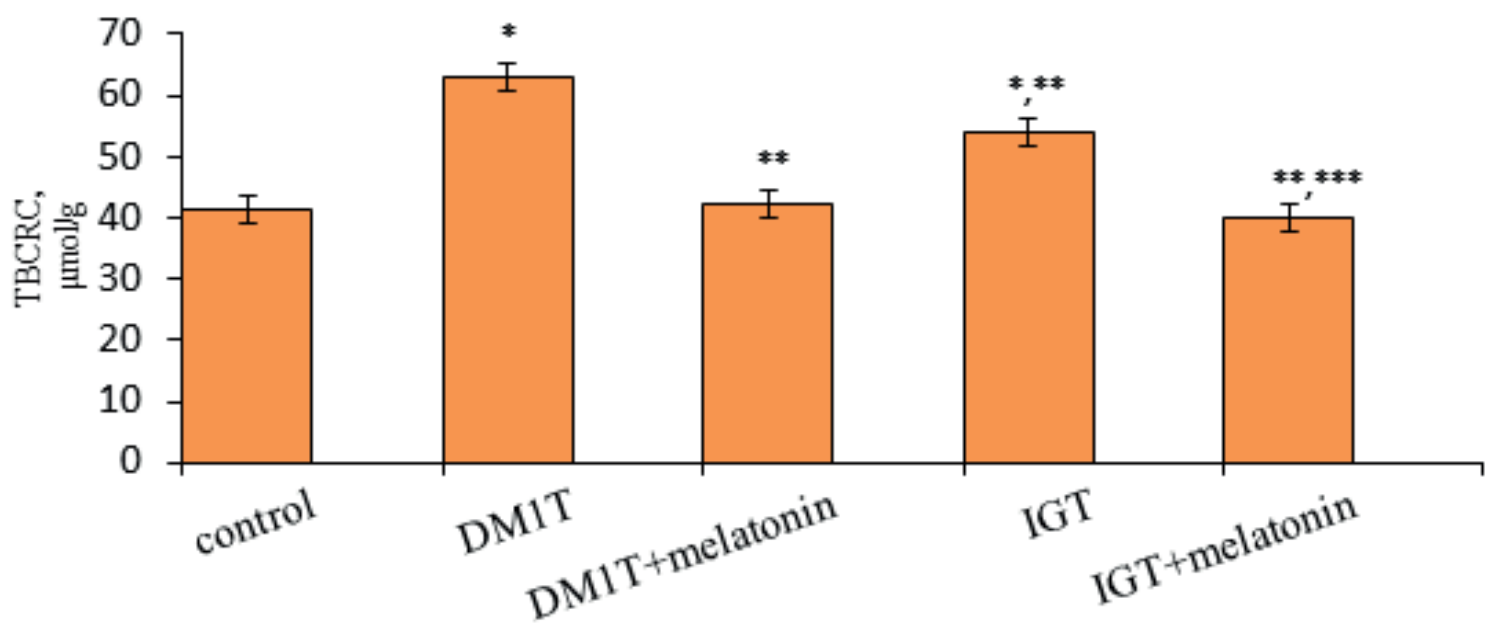

Fig. 4. The levels of TBCRC in muscles of rats $(\mu \mathrm{mol} / \mathrm{g}),(\mathrm{n}=6, \mathrm{x} \pm \mathrm{Sx}): 1 . *, * *, * * *, * * * *-$ changes are reliable $(\mathrm{P} \leq 0.05) .2$. $*$ - concerning control; $* *$ - concerning rats with DM1T; *** - concerning rats with IGT 
Table. Changes of the antioxidant defence in muscles of diabetic rats, $(n=6, x \pm S)$

\begin{tabular}{|c|c|c|c|c|}
\hline $\begin{array}{l}\text { Indexes } \\
\text { Groups }\end{array}$ & $\begin{array}{c}\text { GPx, } \\
\mathrm{nmol} / \min \times \operatorname{mg}\end{array}$ & $\begin{array}{c}\text { G-6-PhD, } \\
\mathrm{nmol} / \mathrm{min} \times \mathrm{mg}\end{array}$ & $\begin{array}{c}\text { GR, } \\
\mathrm{nmol} / \mathrm{min} \times \mathrm{mg}\end{array}$ & $\begin{array}{l}\mathrm{GSH}, \\
\mu \mathrm{mol} / \mathrm{g}\end{array}$ \\
\hline Control group & $40.4 \pm 2.12$ & $3.6 \pm 0.05$ & $0.5 \pm 0.04$ & $0.14 \pm 0.01$ \\
\hline DM1T & $32.3 \pm 3.10^{\mathrm{a}}$ & $1.8 \pm 0.06^{\mathrm{a}}$ & $0.3 \pm 0.06^{\mathrm{a}}$ & $0.08 \pm 0.02^{\mathrm{a}}$ \\
\hline $\mathrm{DM} 1 \mathrm{~T}+$ melatonin & $43.2 \pm 3.04^{\mathrm{b}}$ & $3.8 \pm 0.08^{\mathrm{b}}$ & $0.6 \pm 0.06^{\mathrm{b}}$ & $0.15 \pm 0.02^{\mathrm{b}}$ \\
\hline IGT & $49.3 \pm 3.01^{\mathrm{a} . \mathrm{b}}$ & $4.9 \pm 0.04^{a . b}$ & $0.7 \pm 0.04^{\mathrm{a} . \mathrm{b}}$ & $0.16 \pm 0.03^{b}$ \\
\hline $\mathrm{IGT}+$ melatonin & $45.0 \pm 2.08^{\mathrm{b}}$ & $3.9 \pm 0.08^{b . c}$ & $0.5 \pm 0.04^{b . c}$ & $0.15 \pm 0.02^{b}$ \\
\hline
\end{tabular}

Note: 1 . $a, b, c-$ changes are reliable $(\mathrm{P} \leq 0.05)$.

2. a - concerning control (intact rats);

$\mathrm{b}$ - concerning rats with diabetes mellitus;

$\mathrm{c}$ - concerning rats with IGT

G6PD reduces NADP to NADPH while oxidizing glucose-6-phosphate.The NADPH in turn maintains the level of GSH in cells that helps protect cells against oxidative damage from compounds like peroxides. On the other hand GR, GPx, G-6-PhD activities also depend on the presents of hyperglycemia. In DM1T group of rats activities of GR, GPx, G-6-PhD were decreased on $25 \%(\mathrm{P}=0.0077), 18 \%(\mathrm{P}=0.036)$, $50 \%(\mathrm{P}=0.000014)$ respectively compare with control rats. These results are consistent with the degenerative role of hyperglycemia on cellular reducing equivalent homeostasis and antioxidant defense, and provide further evidence that pharmacological intervention of antioxidants may have significant implications in the prevention of the prooxidant feature of diabetes and protects redox status of the cells.

In the group of rats with preserved normoglycemia (IGT) activities of GR, GPx, G6- $\mathrm{PhD}$ were increased on $37 \%(\mathrm{P}=0.0076)$, $22 \%(\mathrm{P}=0.02), 35 \%(\mathrm{P}=0.000022)$ respectively compare with control rats. Increase of $\mathrm{G} 6 \mathrm{PhD}$ activity in condition of diabetes with IGT is probably a compensatory reaction aimed to reduce of ROS.

NADPH reducing equivalents (that are produced in this reaction) are used for regeneration of glutathione from its oxidized form due to action of NADPH-dependent glutathione reductase. Glutathione neutralizes ROS, both directly and through GPx. We have found the level of GSH lover by $42 \%(\mathrm{P}=0.01)$ in DM1T group of animals compared with control. Melatonin injections was helpful for normalization this index under study.

It is well known, that muscle tissue is dependent on the presence of insulin. In the absence of insulin glucose cannot even enter muscle cells. In the conditions of low glucose influx to muscles there is no substrates for glycolysis, hexose monophosphate shunt and glycogenesis. That's why the activity of G6PD is decreased. We know [18] that pinealectomy, same as its hypofunction caused by permanent lighting, leading to decreased synthesis and secretion of melatonin, which causes insulin resistance and reduce the gene expression of glucose transporter GLUT 4, 2, 1. Overexpression of GLUT4 in skeletal muscle improves glucose homeostasis in animal models of diabetes mellitus and protects against the development of diabetes mellitus. Thus, GLUT4 is an attractive target for pharmacological intervention strategies to control glucose homeostasis. It was detected, that melatonin stimulates glucose transport to skeletal muscle cells via insulin receptor substrate-1 / phosphoinositide 3-kinase (IRS1/PI-3-kinase) pathway, which implies, at the molecular level, its role in glucose homeostasis and possibly in diabetes. Additionally, exposure to light at night and aging, both of which lower endogenous melatonin levels may contribute to the incidence and/or development of diabetes [17] It is logical that the activity of G6PD is 
reduced under diabetes mellitus, whether an administration of melatonin leads to increase its activity, probably due to direct activation [18].

So, enhanced skeletal muscle and fundamental understanding of the biological process are critical for effective glucose homeostasis in metabolic disorders.

Melatonin injections helped to normalize parameters of antioxidant body defense. Physiologically, the key to effective glucose homeostasis is the hormone insulin and insulin sensitivity of target tissues. Enhanced skeletal muscle, by either intrinsic mechanism or physical activity, offers great advantages and benefits in facilitating glucose regulation.

Melatonin besides being safe, lowered the blood glucose significantly without any hypoglycemic effect on their normoglycemic counterparts. It increased glutathione peroxidase, glutathione reductase activities significantly and reduced lipid peroxidation (32\%) and protein carbonylation $(42 \%)$ as well as hemoglobin glycosylation $(45 \%)$. It also increased the glucose-6-phosphate dehydrogenase activitiy in muscles of diabetic rats which plays a critical role in glucose homeostasis. Thus, melatonin has strong potential to regulate glucose homeostasis through enhanced glucose consumption, decreased oxidative stress by activation of the glutathione protection system.

The authors of this study confirm that the research and publication of the results were not associated with any conflicts regarding commercial or financial relations, relations with organizations and/or individuals who may have been related to the study, and interrelations of coauthors of the article.

\section{О.Ю. Кушнір, І.М. Яремій, В.І. Швець, Н.В. Швець}

\section{ВПЛИВ МЕЛАТОНІНУ НА СИСТЕМУ ГЛУ- ТАТІОНУ В СКЕЛЕТНИХ М' ЯЗАХ ЩУРІВ 3 АЛОКСАНОВИМ ДІАБЕТОМ}

Вивчали вплив мелатоніну на базальний вміст глюкози, реактивних сполук тіобарбітурової кислоти (ТБКРС), карбонільних похідних білків, $\mathrm{HbA}_{1 \mathrm{c}}$, глутатіону (GSH), ак- тивність глутатіонредуктази [КФ1.6.4.2] (ГР), глутатіонпероксидази [КФ1.11.1.9] (ГП), глюкозо-6-фосфатдегідрогеназа [КФ1.1.1.49] (Г-6-фДГ) у м'язах щурів з алоксановим діабетом (ЦД1Т). Слід відзначити, що базальний вміст глюкози БГ в крові щурів із ЦД1Т збільшився на 139\%, тоді як у групі щурів 3 діабетом і порушенням толерантності до глюкози (ПТГ) - не відрізнявся від контрольних. Вміст $\mathrm{HbA}_{1 \mathrm{c}}$ у крові тварин з ЦД1Т та ПТГ перевищував контроль на 219 та 123\%, карбонільних груп - на 76 та $36 \%$, ТБКРС - на 58 та 36\% відповідно. Активність ГР, ГП, Г-6-фДГ та вміст GSH були знижені відповідно на $25,18,50$ та 42\% у щурів з ЦД1Т, тоді як у щурів з ПТГ ці показники (крім GSH) були збільшені на 37, 22, 35\% відповідно порівняно з контролем. Введення мелатоніну знизило базальний вміст глюкози на $56 \%$ у щурів ЦД1Т порівняно з вихідним значенням, що супроводжувалося нормалізуванням активності ГР, ГП, Г-6-фДГ, процесів перекисного окислення ліпідів, карбонілювання білка, глікозилювання гемоглобіну, оскільки показники не відрізнялися від контролю. Таким чином, мелатонін має видимий потенціал для регулювання гомеостазу глюкози через посилення іiї споживання, зниження окисного стресу через активацію глутатіонової системи антиоксидантного захисту.

Ключові слова: мелатонін; алоксановий діабет; система глутатіону; скелетні м’язи; щури.

Вищий державний навчальний заклад України «Буковинський державний медичний університет»; e-mail: kushnir@bsmu.edu.ua

\section{О.Ю. Кушнир, И.Н. Яремий, В.И. Швец, Н.В. Швец}

\section{ВЛИЯНИЕ МЕЛАТОНИНА НА СИСТЕМУ ГЛУТАТИОНА В СКЕЛЕТНЫХ МЫШЦАХ АЛЛОКСАНДИАБЕТИЧЕСКИХ КРЫС}

Изучали влияние мелатонина на базальное содержание глюкозы, $\mathrm{HbA}_{1 \mathrm{c}}$, карбонильных производных белков и реактивных соединений тиобарбитуровой кислоты (ТБКРС), содержание восстановленного глутатиона (GSH), активность глутатионредуктазы [КФ1.6.4.2] (ГР), глутатионпероксидазы [КФ1.11.1.9] (ГП), глюкозо-6-фосфатдегидрогеназы [КФ1.1.1.49] (Г-6-фДГ) в мышцах крыс с аллоксановым диабетом (СД1Т). Базальное содержание глюкозы в крови крыс с СД1Т увеличилось на 139\%, тогда как в группе крыс с диабетом и нарушением толерантности к глюкозе (НТГ) - не отличался в сравнении с контролем. Содержание $\mathrm{HbA}_{1 \mathrm{c}}$ в крови животных с СД1Т и НТГ превышало контроль на 219 и 123\%, карбонильных групп - на 76 и $36 \%$, ТБКРС - на 58 и $36 \%$ соответственно. Активность ГР, ГП, Г-6-фДГ и содержание GSH были снижены на $25,18,50$ и $42 \%$ соответственно у крыс с СД1Т, тогда как у крыс с НТГ эти показатели (кроме GSH) были увеличены на $37,22,35 \%$ соответственно по сравнению с контролем. Введение мелатонина снизило базальное содержание глюкозы на $56 \%$ у крыс СД1Т по 
сравнению с исходным уровнем, что сопровождалось нормализацией активности ГР, ГП, Г-6-фДГ, процессов перекисного окисления липидов, карбонилирования белка, гликозилирования гемоглобина, так как показатели не отличались от контроля. Таким образом, мелатонин обладает сильным потенциалом для регулирования гомеостаза глюкозы за счет увеличения ее потребления, а также снижения окислительного стресса за счет активации глутатионовой системы защиты.

Ключевые слова: мелатонин; аллоксановый диабет; система глутатиона; скелетные мышцы; крысы.

\section{REFERENCES}

1. Rahimi-Madiseh M, Malekpour-Tehrani A, Bahmani M, Rafieian-Kopaei M. The research and development on the antioxidants in prevention of diabetic complications. Asian Pac J Trop Med. 2016; 9(9):825-31. doi: 10.1016/j. apjtm.2016.07.001.

2. Lenzen S. The mechanisms of alloxan- and streptozotocininduced diabetes. Diabetologia. 2008; 51(2):216-26.

3. Tang L, Li N, Jian W, Kang Y, Yin B, Sun S, Guo J, Sun L, Ta D. Low-intensity pulsed ultrasound prevents muscle atrophy induced by type 1 diabetes in rats. Skelet Muscle. 2017;7(1):29. doi: 10.1186/s13395-017-0145-7.

4. Carrillo-Vico A, Guerrero JM, Lardone PJ, Reiter RJ. A review of the multiple actions of melatonin on the immune system. Endocrine. 2005;27(2):189-200. doi: 10.1385/ENDO:27:2:189.

5. Mayo JC, Sainz RM, Tan DX, Hardeland R, Leon J, Rodriguez $\mathrm{C}$, et al. Anti-inflammatory actions of melatonin and its metabolites, N1-acetyl-N2-formyl-5-methoxykynuramine (AFMK) and N1-acetyl-5-methoxykynuramine (AMK), in macrophages. J Neuroimmunol. 2005;165(12):139-49. doi: 10.1016/j.jneuroim.2005.05.002.

6. Rodriguez C, Mayo JC, Sainz RM, Antolin I, Herrera F, Martin V, et al. Regulation of antioxidant enzymes: a significant role for melatonin. J Pineal Res. 2004;36(1):1-9.

7. Kushnir OYu, Yaremii IM, Shvetsv VI, Shvets NV. Influence of melatonin on carbohydrate metabolism in the kidney of alloxan diabetic rats. Fiziol Zh. 2017;63(4):64-71.

8. Banaei S, Ahmadiasl N, Alihemmati A. Comparison of the Protective Effects of Erythropoietin and Melatonin on Renal Ischemia-Reperfusion Injury. Trauma Mon. 2016; 21(3):e23005.

9. Pantsiuk K., Kushnir O. Changes of pyruvate kinase activity in the muscle tissue of rats under conditions of alloxan diabetes and administration of melatonin. 28th European Students' Conference: "Genetic Engineering When Chance Meets Choice» (27th - 30th September 2017, Carite-Universitatsmedizin Berlin, Germany). P. 6.

10. Djindjic B, Kostic T, Radovanovic Z, Djindjic N, Lazovic M, Zivic M, Perisic Z, Krstic N. The contributions of fasting and postprandial blood glucose increments to oxidative stress and inflammation in dyslipidemic type 2 diabetic patients with stable ischemic heart disease. Int J Cardiol. 2017;227:611-616. doi: 10.1016/j. ijcard.2016.10.089.

11. Ceban E, Banov P, Galescu A, Botnari V. Oxidative stress and antioxidant status in patients with complicated urolithiasis. J Med Life. 2016; 9(3): 259-62.

12. Vlasova SN, Shabunina EI, Pereslegina IA. The activity of glutathione-dependent enzymes of erythrocytes in chronic liver diseases in children. Laboratory Matter. 1990; 8:19-21.

13. Singh J, Kakkar P. Antihyperglycemic and antioxidant effect of Berberis aristata root extract and its role in regulating carbohydrate metabolism in diabetic rats. J Ethnopharmacol. 2009; 123(1):22-6. doi: 10.1016/j. jep.2009.02.038

14. Kushnir A, Davydenko I. Influence of melatonin on condition of the Langergans isles of the pancreas in alloxan diabetic rats. World of Medicine and Biology. 2009; 5(4):31-5.

15. Tang L, Li N, Jian W, Kang Y, Yin B, Sun S, Guo J, Sun L, Ta D. Low-intensity pulsed ultrasound prevents muscle atrophy induced by type 1 diabetes in rats. Skelet Muscle. 2017; 7(1):29. doi: 10.1186/s13395-017-0145-7.

16. Ullah Asmat, Khan Abad, Khan Ismailb. Diabetes mellitus and oxidative stress-A concise review. Saudi Pharm J. 2016; 24(5): 547-53. doi: 10.1016/j.jsps.2015.03.

17. Lin GJ, Huang SH, Chen YW, Hueng DY, Chien MW, Chia WT, Chang DM, Sytwu HK. Melatonin prolongs islet graft survival in diabetic NOD mice. J Pineal Res. 2009; 47(3):284-92. doi: 10.1111/j.1600-079X.2009.00712.x.

18. Peschke E, Stumpf I, Bazwinsky I, Litvak L, Dralle H, Mühlbauer E. Melatonin and type 2 diabetes - a possible link? J Pineal Res. 2007;42(4):350-8.

19. Coleman SK, Rebalka IA, D'Souza DM, Hawke TJ. Skeletal muscle as a therapeutic target for delaying type 1 diabetic complications. World J Diabetes. 2015; 6(17):1323-36. doi: 10.4239/wjd.v6.i17.1323. 